\title{
Gel Leak
}

National Cancer Institute

\section{Source}

National Cancer Institute. Gel Leak. NCI Thesaurus. Code C63316.

Escape (release, discharge) of gel through an unintended location - as in leakage of ultrasound gel. Escape or release of gel from containment structures - as in gel filled implant leak. 